\title{
Mortality in chemical workers potentially exposed to 2,4-dichlorophenoxyacetic acid (2,4-D) 1945-94: an update
}

\author{
C J Burns, K K Beard, J B Cartmill
}

\begin{abstract}
Objective-To update and add to a previously identified cohort of employees potentially exposed to the herbicide 2,4dichlorophenoxyacetic acid (2,4-D). The putative association between $2,4-\mathrm{D}$ and non-Hodgkin's lymphoma has been debated for more than a decade.

Methods-Cohort members were male employees of The Dow Chemical Company who manufactured or formulated 2,4-D any time from 1945 to the end of 1994. Their mortality experience was compared with national rates and with more than 40000 other company employees who worked at the same location.

Results-330 Deaths were observed among 1517 people compared with 365 expected (standardised mortality ratio $(\mathrm{SMR})=0.90,95 \%$ confidence interval $(95 \% \mathrm{CI}) 0.81$ to 1.01$)$. There were no significantly increased SMRs for any of the causes of death analyzed. When compared with the United States rates, the SMR for non-Hodgkin's lymphoma (NHL) was 1.00 $(95 \%$ CI 0.21 to 2.92$)$. The internal comparison with other Dow employees showed a non-significant relative risk of 2.63, (95\% CI 0.85 to 8.33). Death was attributed to amyotrophic lateral sclerosis (ALS) for three cohort members. Compared with the other company employees, the relative risk was $3.45(95 \%$ CI 1.10 to 11.11). The cases were employed in the manufacture or formulation of 2,4-D at different periods (1947-9, 1950-1, and 1968-86), and for varying durations of time $(1.3,1.8$, and 12.5 years).

Conclusion-There was no evidence of a causal association between exposure to 2,4-D and mortality due to all causes and total malignant neoplasms. No significant risk due to NHL was found. Although not an initial hypothesis, an increased relative risk of ALS was noted. This finding is unsupported by other animal and human studies.

(Occup Environ Med 2001;58:24-30)
\end{abstract}

Keywords: 2,4-dichlorophenoxyacetic acid; phenoxy herbicide; occupation; non-Hodgkin's lymphoma

Herbicides have widespread use in the United States in agriculture, rights of way, and lawn care. One of the most commonly used herbicides in the United States, 2,4dichlorophenoxyacetic acid (2,4-D), has been approved for use for more than 50 years. Given its long and widespread use, 2,4-D has been extensively studied in both animals and humans. Despite the conclusions of a World Health Organisation (WHO) panel stating that 2,4-D has been adequately studied and is not genotoxic, ${ }^{1}$ there remains some controversy over the human carcinogenicity of 2,4-D, particularly related to non-Hodgkin's lymphoma (NHL).

Early case-control studies linked NHL to phenoxy herbicides in Sweden ${ }^{2}$ and Kansas. ${ }^{3}{ }^{4}$ Subsequent case-control studies of NHL, which collected information specific to $2,4-\mathrm{D}$, were inconsistent. One of these, a study conducted in Nebraska, found an increased odds ratio with increasing number of days of 2,4-D use. However, this trend was not found when the data were limited to self respondents. $^{5}$ A related study of canine malignant lymphoma, (similar to NHL in humans) found a positive trend of owner applications of 2,4-D and increased risk. ${ }^{6}$ Reanalyses of these data by independent researchers have been unable to confirm or replicate a dose-response relation. ${ }^{7}$ Other case-control studies of NHL have not found a positive association of frequency of phenoxy herbicide or use of 2,4-D. ${ }^{8-10}$

Cohort studies of farmers, pesticide applicators, and golf course superintendents are also equivocal. Some have suggested a positive association $^{11}{ }^{12}$ whereas others have not. ${ }^{13-15}$ The research efforts to determine the potential of 2,4-D for human health risk have been hindered by the multiplicity of products usedsuch as other herbicides, insecticides, fungicides, fertilisers, and petroleum products. Further complicating this research is the difficulty in determining the level of exposure to 2,4-D of individual people. Such studies are often limited to subjects' memory of past use of the pesticide, typically going back several decades. If the subject is dead, the investigators must rely upon a proxy respondent to provide the exposure information. Not unexpectedly, these data are subject to reporting bias. ${ }^{16}{ }^{17}$ Indeed, a review of more than 100 epidemiology studies relating to $2,4-\mathrm{D}$ pesticides or agriculture, concluded that few studies had adequate exposure assessment to contribute to the understanding of the effects of exposure on human health. ${ }^{18}$

Alternatively, populations of workers who manufacture or formulate 2,4-D tend to provide better exposure data. Three such occupational cohort studies have found no significant excess of NHL. ${ }^{19-21}$ For The Dow Chemical Company cohort, Bond et al found two deaths due to NHL compared with less 
than one expected, among Dow employees potentially exposed to $2,4-\mathrm{D}$ and its derivatives from 1945 to $1982 .{ }^{21}$ In an update to the end of 1986, no new deaths due to NHL occurred. ${ }^{22}$ The purpose of the current study was to add to the original Dow Chemical cohort and update the mortality experience to the end of 1994 .

\section{Methods}

Briefly, 2,4-D has been manufactured, esterified, aminated, formulated, or packaged by The Dow Chemical Company since 1945 in four separate buildings in Midland, Michigan. The original 2,4-D cohort was identified from these four sites from plant rosters (census lists), which were available annually until 1964 and monthly thereafter. As a result, many potentially exposed employees who were working in a production area for less than 1 year (or 1 month, after 1964) may have been excluded.

Subsequent to the identification of the original 2,4-D cohort, the Epidemiology Department of Dow Chemical has ameliorated its employee registry by inputting complete work history information (dates of each job, job title, job change, location, etc) on all employees who worked in Dow United States manufacturing sites since 1940. In depth quality assurance measures have been incorporated to ensure accurate and complete data, including comparing a sample of subjects with the Internal Revenue Service form 941-schdule A. ${ }^{23}$ The current database is now periodically updated and appended from information provided by Dow's computerised personnel system. All full time employees at Midland who worked more than 3 days are included in the database. To identify additional eligible subjects, the 1945-82 cohort was reidentified by replicating the inclusion criteria defined in the study file and with the epidemiology database. Also identified were workers potentially exposed after 1982. The entire cohort of potentially exposed employees from 1945 to the end of 1994 was selected from job categories and department codes within the computerised work history.

A job exposure matrix was previously defined for the 1945-82 cohort in which the industrial hygienist ranked each job into low, moderate, or high categories based on potential time weighed average (TWA) exposure (less than $0.1,0.1-1.0$, or more than $1.0 \mathrm{mg} / \mathrm{m}^{3}$ ). The 1998 American Conference of Governmental Industrial Hygienists (ACGIH) recommended that the threshold limit value (TLV) should be $10 \mathrm{mg} / \mathrm{m}^{3}$ for 2,4-D. Because process improvements have led to significantly reduced exposure over time, we added a "very low" rank to the job exposure matrix for the 1983-94 jobs which had non-detectable exposure monitoring concentrations or which involved less than $50 \%$ time in a low exposure area. These employees were included in the study because the potential for exposure remained, even though exposure was not documented in the industrial hygiene studies. Cumulative exposure was then calculated for each subject by summing the product of the number of years spent on each job and a weight assigned to each
TWA (0.005, 0.05, 0.5, and 5). Cumulative exposure was calculated for all four categories and the cumulative dose index was expressed as follows: very low $(<0.05)$, low $(0.05-0.49)$, moderate $(0.5-4.9)$, and high $(\geqslant 5)$.

Exposures to 2,4-D were primarily to particulates, as $2,4-\mathrm{D}$ is a solid at ambient temperatures. Exposures to vapour were also a possibility when 2,4-D was in the molten form. These people were likely to be exposed to additional chemicals during their work in the 2,4-D plants and subsequent Dow employment elsewhere. These potential exposures would have been significantly varied based on the plant, the period, and the job. However, the common factor for this cohort was potential exposure to 2,4-D.

Person-years at risk for mortality were accumulated for each subject beginning on 1 January 1945 , or on the date of the subject's first potentially exposed job, whichever was later. Vital status was followed up to the earliest of (a) the date of death, (b) the date of last contact for employees lost to follow up, or (c) 31 December 1994. Cause of death and vital status were determined from the company epidemiology database. Information on vital status is periodically updated with information provided by company records, the National Death Index, and the Social Security Administration. Mortality outcome data are derived from copies of the death certificates. Causes of death were coded by a certified nosologist according to the revision of the international classification of diseases (ICD) in effect at the time of death. All codes were then converted to the 8th revision (ICD-8) for analytical purposes.

\section{STATISTICS}

The mortality experience of the study cohort was compared with mortality in the United States with computer software developed by Monson. ${ }^{24}$ The program calculates expected numbers of deaths in 57 categories by summing across 5 year age and calendar-year intervals. The ratio of observed to expected deaths, or standardised mortality ratios (SMRs), was calculated with United States rates. The 95\% confidence intervals (95\% CIs) were calculated around the SMR point estimates. As less than $4 \%$ of the cohort was non-white, white male reference rates were used. Life table analyses were performed for the entire follow up period and with allowance for a 20 year minimum induction latency period. For the latency analyses, the person-years at risk began accruing 20 years from the first date of employment in an exposed job. People who died within that period were excluded.

Rates for NHL are not included in the 57 major and minor causes of death used by the Monson program. More detailed rate files for 99 causes of death were obtained from the National Institute for Occupational Safety and Health (NIOSH) for the years 1960-94. Person-years at risk between 1945 and 1960 were excluded, as were 17 people who died before 1960. We used the life table analysis program from NIOSH (PC LTAS, version 1.0) 
to calculate the SMRs for NHL and the other lymphatic and haematopoietic cancers. ${ }^{25}$

To control for the healthy worker effect, a comparative mortality analysis was conducted with an internal reference population of all other Dow Chemical employees at Midland. Person-years at risk and observed deaths were tabulated for each 2,4-D exposure group, and comparisons were made against the internal control group stratifying by age, calendar year, and pay status (hourly $v$ salaried) with the Mantel-Haenszel method adapted for cohort studies. ${ }^{26}$ A relative risk (RR) was calculated for each dose concentration relative to the unexposed reference group. Ninety five per cent confidence intervals were calculated for the RR point estimates, and trend tests performed with Mantel's single degree of freedom $\chi^{2}$ test. $^{27}$ Analyses were repeated with a 20 year lagging period for exposures. ${ }^{28}$ People with less than 20 years of follow up from the date of recruitment in a $2,4-\mathrm{D}$ job were counted in the very low exposure classification. They were not excluded from the analyses as was done with the latency analyses.

\section{Results}

We identified 1567 people who were potentially exposed to 2,4-D between 1945 and 1994, inclusive (table 1). One subject died outside the United States. Death certificates were obtained for all remaining deaths. Most of the cohort was first exposed before the age of 35 . Only 50 women were in the cohort. All women were living at the end of 1994, except for one who died from external causes. Due to the few women, the limited number of person-years at risk, and the single death due to causes unrelated to exposure to $2,4-\mathrm{D}$, detailed statistical analyses were confined to men.

Included were 863 male subjects from the original 2,4-D cohort, although previous publications of the cohort have reported on 878 subjects. Excluded were 14 women and three part time workers (two of whom were also women). Part time workers do not meet the criteria for entry into the current epidemiology

Table 1 Vital status and employment characteristics for workers potentially exposed to 2,4-D (1945-94)

\begin{tabular}{|c|c|c|c|c|}
\hline & \multicolumn{2}{|l|}{ Men } & \multicolumn{2}{|c|}{ Women } \\
\hline & $n$ & $\%$ & $n$ & $\%$ \\
\hline Employees (n) & 1517 & 100 & 50 & 100 \\
\hline \multicolumn{5}{|c|}{ Vital status on 31 December 1994: } \\
\hline Alive & 1185 & 78.1 & 49 & 98.0 \\
\hline Dead & 330 & 21.8 & 1 & 2.0 \\
\hline Lost to follow up & 2 & $<1$ & 0 & 0 \\
\hline \multicolumn{5}{|c|}{ Age at first exposure (y): } \\
\hline$<25$ & 579 & 38.2 & 12 & 24.0 \\
\hline $25-34$ & 583 & 38.4 & 24 & 48.0 \\
\hline $35-44$ & 249 & 16.4 & 11 & 22.0 \\
\hline$\geqslant 45$ & 106 & 7.0 & 3 & 6.0 \\
\hline \multicolumn{5}{|l|}{ Year of first exposure: } \\
\hline$<1950$ & 289 & 19.1 & 0 & 0 \\
\hline 1950-9 & 341 & 22.5 & 0 & 0 \\
\hline $1960-9$ & 347 & 22.9 & 0 & 0 \\
\hline 1970-9 & 266 & 17.5 & 11 & 22.0 \\
\hline $1980-2$ & 25 & 1.7 & 2 & 4.0 \\
\hline$\geqslant 1983$ & 249 & 16.4 & 37 & 74.0 \\
\hline \multicolumn{5}{|c|}{ Years since first exposure: } \\
\hline$<10$ & 236 & 15.6 & 35 & 70.0 \\
\hline $10-19$ & 191 & 12.6 & 15 & 30.0 \\
\hline $20-29$ & 365 & 24.1 & 0 & 0 \\
\hline$\geqslant 30$ & 725 & 47.8 & 0 & 0 \\
\hline
\end{tabular}

Table 2 Distribution of 2,4-D male cohort by cumulative dose and duration of exposure

\begin{tabular}{lccccc}
\hline \multicolumn{5}{c}{ Duration $(y)^{*}$} \\
\cline { 2 - 6 } Cumulative dose & \multicolumn{1}{c}{$1-4.9$} & $5-14.9$ & $\geqslant 15$ & Total \\
\hline Original cohort & $(1945-82):$ & & & & \\
Very low & 169 & 1 & 0 & 0 & 170 \\
Low & 152 & 106 & 16 & 0 & 274 \\
Moderate & 92 & 99 & 41 & 18 & 250 \\
High & 0 & 86 & 48 & 35 & 169 \\
Total & 413 & 292 & 105 & 53 & 863 \\
Newly identified & $(1945-82):$ & & & & \\
Very low & 240 & 0 & 0 & 0 & 240 \\
Low & 87 & 2 & 0 & 0 & 89 \\
Moderate & 71 & 3 & 1 & 0 & 75 \\
High & 0 & 1 & 0 & 0 & 1 \\
Total & 398 & 6 & 1 & 0 & 405 \\
Newly identified & $(1983-94):$ & & & & \\
Very low & 121 & 55 & 4 & 0 & 180 \\
Low & 0 & 52 & 17 & 0 & 69 \\
Moderate & 0 & 0 & 0 & 0 & 0 \\
High & 0 & 0 & 0 & 0 & 0 \\
Total & 121 & 107 & 21 & 0 & 249 \\
\hline
\end{tabular}

^Adjusted for breaks in service and accumulated to the end of 1994.

database. An additional 405 employees were identified who would have been eligible for the original cohort, if the work history records had been computerised at the time. Most of these subjects were potentially exposed for less than a year with resulting very low and low cumulative dose indices (table 2). Also new to the updated cohort were 249 men who began working in 2,4-D production areas since 1983. These jobs were classified as low or very low exposure.

The resulting cohort under study comprised 1517 male employees who contributed 39799 person-years at risk for an average follow up of 26.2 years. There were 330 deaths, representing an additional 198 deaths since the previous update. The results of the life table analyses are presented in table 3. Fewer deaths than expected were found due to all causes and due to all malignant neoplasms. A significantly decreased SMR was found for non-malignant respiratory diseases for zero years latency (SMR 0.35, 95\% CI 0.15 to 0.68 ) and for 20 years latency (SMR 0.38, 95\% CI 0.15 to $0.77)$. No significantly increased SMR was found for any of the underlying causes of death categories analysed. No cases of soft tissue sarcoma were found upon a review of the death certificates.

The three deaths due to NHL in this cohort were equivalent to the number of expected NHL deaths in the United States (SMR 1.00, $95 \%$ CI 0.21 to 2.92 ). All three subjects were first employed before 1965. However, one was not identified on the employee rosters used to create the original cohort. This employee was employed in the 2,4-D plant for less than 5 months during 1955 in a low exposure job and died 23 years later. The other two deaths occurred a relatively short time after first exposure (within 3 and 11 years). Due to their short time between date of recruitment in a 2,4-D job and date of death, they were excluded from the 20 year latency analyses.

The results of the internal analyses are presented in table 4 . There were 40600 unexposed manufacturing workers in the comparison group with 14516 deaths and more than 
Table 3 Observed and expected deaths and risk statistics among male employees allowing for 0 and 20 years of latency using United States white male mortalities to calculate expected deaths

\begin{tabular}{|c|c|c|c|c|c|c|c|c|}
\hline \multirow[b]{2}{*}{ Cause of death (ICDA-8) } & \multicolumn{4}{|c|}{ Entire follow up period } & \multicolumn{4}{|c|}{$\geqslant 20$ Years since recruitment } \\
\hline & Obs & $\operatorname{Exp}$ & $S M R$ & $95 \% C I$ & Obs & $\operatorname{Exp}$ & $S M R$ & $95 \% C I$ \\
\hline All causes $(000-E 999)$ & 330 & 365.0 & 0.90 & 0.81 to 1.01 & 241 & 255.0 & 0.94 & 0.83 to 1.07 \\
\hline Infectious and parasitic diseases (001-139) & 5 & 4.2 & 1.19 & 0.38 to 2.77 & 4 & 2.3 & 1.74 & 0.47 to 4.44 \\
\hline All malignant neoplasms (140-209) & 83 & 86.9 & 0.95 & 0.76 to 1.18 & 66 & 66.9 & 0.99 & 0.76 to 1.26 \\
\hline Cancer of digestive organs and peritoneum (150-159) & 16 & 21.5 & 0.74 & 0.43 to 1.21 & 15 & 16.5 & 0.91 & 0.51 to 1.50 \\
\hline Cancer of respiratory system $(160-163)$ & 31 & 32.9 & 0.94 & 0.64 to 1.34 & 26 & 26.3 & 0.99 & 0.64 to 1.45 \\
\hline Cancer of prostate (185)) & 7 & 5.2 & 1.34 & 0.54 to 2.77 & 5 & 4.7 & 1.07 & 0.35 to 2.50 \\
\hline Cancer of testis and other genitalia (186-187) & 1 & 0.5 & 2.24 & 0.03 to 12.47 & 0 & 0.1 & - & 0.0 to 29.01 \\
\hline Cancer of bladder (188) & 1 & 2.0 & 0.50 & 0.01 to 2.78 & 0 & 1.6 & - & 0.0 to 2.24 \\
\hline Cancer of kidney (189) & 2 & 2.2 & 0.90 & 0.10 to 3.25 & 2 & 1.7 & 1.19 & 0.13 to 4.30 \\
\hline Cancer of brain and other nervous system tissues (191-192) & 3 & 2.7 & 1.09 & 0.22 to 3.19 & 2 & 1.7 & 1.17 & 0.13 to 4.22 \\
\hline Lymphatic and haematopoietic cancer (200-209) & 9 & 8.5 & 1.06 & 0.48 to 2.01 & 7 & 5.8 & 1.21 & 0.48 to 2.48 \\
\hline Non-Hodgkin's lymphoma $(200,202)^{\star}$ & 3 & 3.0 & 1.00 & 0.21 to 2.92 & 1 & 2.8 & 0.36 & 0.01 to 2.00 \\
\hline Hodgkin’s disease $(201)^{\star}$ & 1 & 0.6 & 1.54 & 0.04 to 8.56 & 1 & 0.6 & 1.70 & 0.04 to 9.43 \\
\hline Leukaemia and aleukaemia $(204-207)^{\star}$ & 4 & 3.1 & 1.30 & 0.35 to 3.32 & 4 & 2.9 & 1.39 & 0.38 to 3.56 \\
\hline Myeloma $(203)^{\star}$ & 1 & 1.2 & 0.80 & 0.02 to 4.46 & 1 & 1.2 & 0.84 & 0.02 to 4.69 \\
\hline Other and ill defined cancer $(171,194-199)$ & 10 & 6.6 & 1.51 & 0.77 to 2.70 & 8 & 5.1 & 1.57 & 0.73 to 2.99 \\
\hline Benign neoplasms (210-239) & 1 & 1.1 & 0.95 & 0.01 to 5.30 & 0 & 0.7 & - & 0.0 to 5.47 \\
\hline Disease of nervous and sensory organs $(320-389)$ & 6 & 4.2 & 1.42 & 0.52 to 3.09 & 5 & 2.9 & 1.72 & 0.56 to 4.02 \\
\hline Diseases of circulatory system $(390-458)$ & 158 & 167.0 & 0.95 & 0.80 to 1.11 & 130 & 124.3 & 1.05 & 0.87 to 1.24 \\
\hline Non-malignant respiratory diseases $(460-519)$ & 8 & 23.2 & 0.35 & 0.15 to 0.68 & 7 & 18.7 & 0.38 & 0.15 to 0.77 \\
\hline Pneumonia (480-486) & 4 & 7.2 & 0.56 & 0.15 to 1.43 & 3 & 5.4 & 0.55 & 0.11 to 1.62 \\
\hline Digestive diseases $(520-577)$ & 11 & 16.8 & 0.66 & 0.33 to 1.17 & 7 & 10.5 & 0.66 & 0.27 to 1.37 \\
\hline Genitourinary diseases $(580-629)$ & 4 & 4.2 & 0.96 & 0.26 to 2.46 & 3 & 2.8 & 1.07 & 0.22 to 3.13 \\
\hline All external causes (E800-E999) & 42 & 40.3 & 1.04 & 0.75 to 1.41 & 11 & 14.5 & 0.76 & 0.38 to 1.36 \\
\hline People (n) & 1517 & & & & 1005 & & & \\
\hline Person-years & 39799 & & & & 14356 & & & \\
\hline
\end{tabular}

${ }^{\star}$ United States rates from NIOSH life table analysis program (LTAS).

one million person-years. These analyses have the advantage of a comparison population similar to the exposed cohort as well as separating the RR by dose level. The RR was slightly higher than the corresponding SMR for all categories. The overall RRs for deaths due to all causes and all cancer were 1.10 (95\% CI 0.98 to 1.22 ) and 1.05 (95\% CI 0.85 to 1.30 ), respectively.

Expected rates for NHL (ICD 200 and 202) were computed with the internal Dow Chemical population. The resulting pooled RR for NHL was 2.63 (95\% CI 0.85 to 8.33 ). Two of the deaths due to NHL occurred in men with moderate cumulative exposure, suggestive of a dose response. However, due to the short period between first exposure and death, all deaths were classified with very low cumulative exposure after lagging the exposure by 20 years.

Closer inspection of individual death certificates showed that three of the six deaths from diseases of nervous and sensory organs were attributed to amyotrophic lateral sclerosis (ALS). The RR was significantly increased when we limited the analyses to deaths due to ALS (RR 3.45, 95\% CI 1.10 to 11.11). Lagged analyses were similar as all three employees died more than 20 years after their first exposure. The cases were employed in the manufacture or formulation of 2,4-D at different periods (1947-9, 1950-1, and 1968-86), and for varying durations of time $(1.3,1.8$, and 12.5 years).

\section{Discussion}

The previous Dow Chemical 2,4-D cohort studies have been criticised for their small sample size. Indeed, for rare diseases such as NHL, it is difficult to identify any cohort sufficiently large to attain a great deal of statistical power, especially one that would have the nearly complete follow up of this research. This update of the Dow Chemical 2,4-D cohort provided 8 additional years of follow up data for the original cohort and nearly 20000 person-years. The cohort was expanded by more than 600 employees and 198 additional deaths were observed. We found no increased risk of NHL compared with the United States population. When compared to the other Midland Dow Chemical employees, the relative risk was increased, but with a wide confidence interval (95\% CI 0.85 to 8.33 ). We cannot explain why the expected number of deaths attributed to NHL is higher in the United States than in our local comparison population. The three employees who died of NHL were occupationally exposed to $2,4-\mathrm{D}$ for only $4.1,4.7$, and 31.2 months. None of the workers held the same type of job, and the last death due to NHL occurred in 1979. These exposure characteristics are not indicative of a causal association of 2,4-D and NHL. This is consistent with the lifetime studies in the mouse, rat, and dog that have found no oncogenic response to $2,4-\mathrm{D} .^{29} 30$

Cancers such as NHL are not uncommonly found among patients with immunodeficiencies, particularly in patients infected with human immunodeficiency virus (HIV). Some have suggested that immunotoxicity may be the mechanism by which some pesticides may be carcinogenic. $^{31} 32$ The supporting evidence is inconclusive. Immunosuppressive effects in mice were found after acute high doses of n-butylester of 2,4-D, although the authors, Blakley and Schiefer, concluded that "it is unlikely that 2,4-D esters will have any major immunotoxicological significance in agricultural communities." ${ }^{\prime 3}$ Two other mouse studies found immunostimulatory effects and no effects. $^{34}{ }^{35}$ The reason for the disparate findings of the three studies has not been clarified. Results of subchronic and chronic toxicology 
Table 4 Mortality summary by cumulative dose of exposure to 2,4-D relative to 40600 unexposed male workers from the same manufacturing location, ( $R R=1.00$ for unexposed)

\begin{tabular}{|c|c|c|c|c|c|c|c|c|}
\hline \multirow[b]{3}{*}{ Cause of death (ICDA-8) } & \multirow{3}{*}{$\begin{array}{l}\text { Cumulative } \\
\text { dose }\end{array}$} & \multicolumn{6}{|c|}{ Exposure lagged } & \multirow[b]{3}{*}{$95 \% C I$} \\
\hline & & \multicolumn{3}{|l|}{$0 y$} & \multicolumn{3}{|l|}{$20 y$} & \\
\hline & & Obs & $\operatorname{Exp}$ & $R R$ & Obs & $\operatorname{Exp}$ & $R R$ & \\
\hline \multirow[t]{5}{*}{ All causes (000-E999) } & Very low & 90 & 82.2 & 1.09 & 151 & 143.6 & 1.05 & \\
\hline & Low & 70 & 62.3 & 1.12 & 46 & 38.5 & 1.20 & \\
\hline & Moderate & 93 & 84.9 & 1.10 & 73 & 62.9 & 1.16 & \\
\hline & High & 77 & 72.2 & 1.07 & 60 & 56.7 & 1.06 & \\
\hline & Total & 330 & 302.2 & 1.10 & & & & 0.98 to 1.22 \\
\hline \multirow[t]{5}{*}{ All cancer (140-209) } & Very low & 28 & 21.7 & 1.29 & 38 & 34.9 & 1.09 & \\
\hline & Low & 12 & 16.1 & 0.75 & 9 & 10.7 & 0.84 & \\
\hline & Moderate & 24 & 22.3 & 1.08 & 19 & 17.6 & 1.08 & \\
\hline & High & 19 & 19.0 & 1.00 & 17 & 15.8 & 1.08 & \\
\hline & Total & 83 & 79.1 & 1.05 & & & & 0.85 to 1.30 \\
\hline \multirow[t]{5}{*}{ All lymphopoietic (200-209) } & Very low & 1 & 2.4 & 0.42 & 3 & 4.3 & 0.71 & \\
\hline & Low & 1 & 1.8 & 0.56 & 1 & 1.0 & 0.96 & \\
\hline & Moderate & 3 & 2.3 & 1.28 & 1 & 1.7 & 0.60 & \\
\hline & High & 4 & 2.0 & 2.05 & 4 & 1.5 & 2.71 & \\
\hline & Total & 9 & 8.5 & 1.06 & & & & 0.55 to 2.08 \\
\hline \multirow[t]{5}{*}{ Non-Hodgkin's lymphoma $(200,202)$} & Very low & 1 & 0.3 & 3.28 & 3 & 0.7 & 4.49 & \\
\hline & Low & 0 & 0.2 & 0.00 & 0 & 0.1 & 0.00 & \\
\hline & Moderate & 2 & 0.3 & 6.11 & 0 & 0.2 & 0.00 & \\
\hline & High & 0 & 0.3 & 0.00 & 0 & 0.2 & 0.00 & \\
\hline & Total & 3 & 1.1 & 2.63 & & & & 0.85 to 8.33 \\
\hline \multirow[t]{5}{*}{ Nervous and sensory organs $(320-380)$} & Very low & 0 & 0.8 & 0.00 & 1 & 1.3 & 0.75 & \\
\hline & Low & 2 & 0.6 & 3.20 & 1 & 0.4 & 2.27 & \\
\hline & Moderate & 3 & 0.9 & 3.52 & 3 & 0.7 & 4.42 & \\
\hline & High & 1 & 0.8 & 1.30 & 1 & 0.6 & 1.55 & \\
\hline & Total & 6 & 3.2 & 1.92 & & & & 0.85 to 4.35 \\
\hline \multirow{5}{*}{ Amyotrophic lateral sclerosis (348.0) } & Very low & 0 & 0.2 & 0.00 & 0 & 0.4 & 0.00 & \\
\hline & Low & 0 & 0.2 & 0.00 & 0 & 0.1 & 0.00 & \\
\hline & Moderate & 2 & 0.2 & 8.04 & 2 & 0.2 & $\begin{array}{c}10.2 \\
0\end{array}$ & \\
\hline & High & 1 & 0.2 & $4.54^{\star}$ & 1 & 0.2 & 5.57 & \\
\hline & Total & 3 & 1.0 & 3.45 & & & & 1.10 to 11.11 \\
\hline \multirow[t]{5}{*}{ Non-malignant respiratory disease $(460-519)$} & Very low & 3 & 5.0 & 0.60 & 4 & 7.4 & 0.55 & \\
\hline & Low & 1 & 3.9 & 0.26 & 0 & 2.9 & 0.00 & \\
\hline & Moderate & 1 & 5.5 & 0.18 & 1 & 4.7 & 0.21 & \\
\hline & High & 3 & 5.1 & $0.58^{\star}$ & 3 & 4.5 & $\begin{array}{l}0.66 \\
\star\end{array}$ & \\
\hline & Total & 8 & 19.2 & 0.41 & & & & 0.21 to 0.81 \\
\hline \multirow[t]{5}{*}{ All digestive system diseases $(520-577)$} & Very low & 7 & 3.1 & 2.28 & 9 & 5.5 & 1.64 & \\
\hline & Low & 1 & 2.3 & 0.43 & 0 & 1.4 & 0.00 & \\
\hline & Moderate & 2 & 3.2 & 0.63 & 1 & 2.3 & 0.44 & \\
\hline & High & 1 & 2.7 & 0.37 & 1 & 2.0 & 0.49 & \\
\hline & Total & 11 & 11.3 & 0.98 & & & & 0.54 to 1.79 \\
\hline \multirow[t]{5}{*}{ External causes (E800-E999) } & Very low & 14 & 9.2 & 1.52 & 33 & 20.9 & 1.58 & \\
\hline & Low & 13 & 6.6 & 1.96 & 4 & 1.9 & 2.11 & \\
\hline & Moderate & 9 & 7.5 & 1.21 & 3 & 2.9 & 1.04 & \\
\hline & High & 6 & 5.0 & 1.20 & 2 & 2.3 & 0.86 & \\
\hline & Total & 42 & 28.3 & 1.49 & & & & $1.10-2.04$ \\
\hline
\end{tabular}

Very low $=<0.05 ;$ low $=0.05-0.49 ;$ moderate $=0.5-4.9$; and high $=\geqslant 5$.

${ }^{\star} \mathrm{p}<0.05$, test for trend.

studies in the dog have found that $2,4-\mathrm{D}$ is not immunotoxic. $^{30}$

Contributing to the debate is a human study of 10 farmers for which blood samples were collected before and after application of 2,4-D and another phenoxy herbicide. ${ }^{36}$ Based upon concentrations of lymphocyte subsets-for example, circulating $\mathrm{T}$ helper cells, natural killer cells, etc-Faustini et al concluded that the participants experienced immunosuppressive effects due to exposure to phenoxy herbicides. No external control group was investigated. A control group - such as farmers who were merely cultivating - is important as exposure to sunlight may ${ }^{37}$ or may not ${ }^{3839}$ be immunosuppressive.

If 2,4-D were immunosuppressive, not only an excess of lymphatic and haematopoietic deaths, but also an excess of infectious and opportunistic diseases would be expected. In the current study, we found no significant excess of deaths due to infectious and parasitic diseases (SMR 1.19, 95\% CI 0.38 to 2.77 ), pneumonia (SMR 0.56, 95\% CI 0.15 to 1.43 ), or lymphatic and haematopoietic cancer (SMR $1.06,95 \%$ CI 0.48 to 2.01 ).

A non-significant increased SMR was found for ill defined cancers. This increase was similarly found in the previous Dow Chemical studies. ${ }^{2122}$ All other and ill defined cancers had unspecified sites. By definition, these cancers are difficult to interpret as a group because the site of origin is unknown.

An unexpected significant excess of deaths attributed to ALS was found. Increased mortality from ALS was not an initial hypothesis in this study, as extensive state of the art animal toxicology studies have shown no evidence of 2,4-D toxicity to the nervous system, ${ }^{40}$ nor have other cohort studies of people with exposure to 2,4-D reported increased rates of ALS. ${ }^{11}{ }^{19}$ The disease ALS is a largely fatal neurological disease with an unknown aetiology. A plethora of risk factors from heavy metals, trauma, and occupation, to physical activity have been investigated, but only sex (male) and genetic predisposition seem to be consistently found. ${ }^{4142}$ In the context of 2,4-D, 
exposure to pesticides and agricultural chemicals have shown no significant association in several studies. ${ }^{43-45}$ A significant association of exposure to pesticides was found in a recent case-control study of ALS. ${ }^{46}$ However, the investigators did not find a significant association of exposure to herbicides.

The human health significance of the current ALS finding is unknown. Whether the significant RR of ALS found is a true or false positive must be questioned. The molecule 2,4-D does not bioaccumulate, is rapidly cleared from the body, and is excreted unchanged within 48 hours. The paucity of confirming animal or human data on neurotoxicity of 2,4-D and the lack of any association of herbicides with ALS suggests that the three cases of ALS in this cohort are unrelated to exposure to 2,4-D.

Overall this update was limited by the unavailability of potentially confounding lifestyle factors such as diet and smoking. The study is also limited by the end point of mortality. Mortality is greatly influenced by the stage of disease at diagnosis and the quality of treatment, which may in turn be influenced by social factors such as education, access to health care, and membership to a health insurance plan. Incidence studies, however, are also problematic because there is not a national tumour registry system in the United States. The major limitation of these studies, as noted by other Dow Chemical investigators, is finding the residential data for employees that have left the company. ${ }^{47} 48$

Conversely, the current study had several strengths. Follow up of the cohort was nearly $100 \%$ complete. We were also able to use an internal comparison population. National mortalities, although more stable, may introduce bias because workers must initially be healthy to gain employment and having access to health insurance may reduce early mortality. Another strength of the current cohort is that potential exposure to 2,4-D has been estimated from industrial hygiene monitoring data. As well as objective exposure data, the cohort members were potentially exposed to $2,4-\mathrm{D}$ on a daily basis. This contrasts with farmers who typically only apply the herbicide a few times each year and then may apply a myriad of other herbicides, insecticides, and fungicides over their lifetime. We were also not reliant upon the memory of the cohort members to estimate exposure.

\section{Conclusion}

In summary, this study represents an updated cohort of workers potentially exposed to $2,4-\mathrm{D}$. In general, we found no evidence of an increased risk of death due to all causes or total malignant neoplasms. No significant risk of NHL was found. A significantly reduced SMR was found for non-malignant respiratory diseases. A higher than expected number of cases of ALS was found. This finding is not consistent with previous human or animal studies and may be unrelated to exposure to $2,4-\mathrm{D}$.

All authors were employed by The Dow Chemical Company. The Dow Chemical Company and Dow AgroSciences funded this study. We greatly appreciate the efforts of Monica Chau and
Ken Bodner for their programming expertise.

1 World Health Organization Core Assessment Group. Pesticide residues in food - 1996; toxicological evaluations. Foint meeting on pesticide residues. Rome, Italy: WHO, 16-25 September 1996.

2 Hardell L, Eriksson M, Lenner P, et al. Malignant lymphoma and exposure to chemicals especially organic solvents, chlorophenols and phenoxy acids: a case-control study. Br f Cancer 1981;43:169-76.

3 Hoar SK, Blair A, Homes FF, et al. Agricultural herbicide use and risk of lymphoma and soft-tissue sarcoma. $\mathscr{F} A M A$ 1986;256:1141-7.

4 Correction. FAMA 1986;256:3351.

5 Zahm SH, Weisenburger, Babbitt PA, et al. A case-control study of non-Hodgkin's lymphoma and the herbicide 2,4-dichlorophenoxyacetic acid (2,4-D) in eastern $\mathrm{Ne}$ braska. Epidemiology 1990;1:349-56.

6 Hayes HM, Tarone RE, Cantor KP, et al. Case-control study of canine malignant lymphoma: positive association with dog owner's use of 2,4-dichlorophenoxyacetic acid herbidog owner's use of 2,4-dichlorophenoxyace
cides. $\mathcal{F}$ Natl Cancer Inst 1991;83:1226-31.

7 Kaneene JB, Miller RA. Subsequent analysis of 2,4-D use Kaneene JB, Miller RA. Subsequent analysis of 2,4-D use
and the occurrence of canine malignant lymphoma. Vet Hum Toxicol 1999;41:164-70.

8 Cantor KP, Blair A, Everett G, et al. Pesticides and other agricultural risk factors for non-Hodgkin's lymphoma among men in Iowa and Minnesota. Cancer Res 1992;52: 2447-55.

9 Pearce NE. Phenoxy herbicides and non-Hodgkin's lymphoma in New Zealand: frequency and duration of herbicide use. Br F Ind Med 1989;46:143-4.

10 Woods JS, Polissar L, Severson RK. Soft tissue sarcoma and non-Hodgkin's lymphoma in relation to phenoxy herbicide and chlorophenol exposure in western Washington. $\mathcal{F}$ Natl Cancer Inst 1987;78:899-910.

$11 \mathrm{Zahm} \mathrm{SH}$. Mortality study of pesticide applicators and other employees of a lawn care service company. F Occup Environ Med 1997;39:1055-67.

12 Kross BC, Burmeister LF, Ogilvie LK, et al. Proportionate mortality study of golf course superintendents. Am $\mathcal{F}$ Ind Med 1996;29:501-6.

13 Morrison HI, Semenciw RM, Wilkins K, et al. NonHodgkin's lymphoma and agricultural practices in the Hodgkin's lymphoma and agricultural practices in the prairie provinces

14 Green LM. A cohort morality study of forestry workers exposed to phenoxy acid herbicides. Br F Ind Med 1991;48: 234-8.

15 Fleming LE, Bean JA, Rudolph M, et al. Mortality in a cohort of licenced pesticide applicators in Florida. Occup Environ Med 1999;56:14-21.

16 Johnson RA, Mandel JS, Gibson RW, et al. Data on prior pesticide use collected from self and proxy respondents. Epidemiology 1993;4:157-64

17 Olsen GW, Bodner KM. The effect of the type of respondent of risk estimates of pesticide exposure in a nonHodgkin's lymphoma case-control study. F Agromed 1996; 3:37-49.

18 Munro IC, Carlo GL, Orr JC, et al. A comprehensive, integrated review and evaluation of the scientific evidence relating to the safety of the herbicide $2,4-\mathrm{D}$. Fournal of the American College of Toxicology 1992;11.

19 Coggon D, Pannett B, Winter P. Mortality and incidence of cancer at four factories making phenoxy herbicides. $B r f$ Ind Med 1991;48:173-8.

20 Lynge E. Cancer incidence in Danish phenoxy herbicide workers, 1947-93. Environ Health Perspect 1998;106(suppl 2);683-8.

21 Bond GG, Wetterstroem NH, Roush GJ, et al. Cause specific mortality among employees engaged in the manufacture, formulation, or packaging of 2,41988;45:98-105.

22 Bloemen LJ, Mandel JS, Bond GG, et al. An update of mortality among chemical workers potentially exposed to the herbicide 2,4-dichlorophenoxyacetic acid and its derivatives. F Occup Med 1993;35:1208-12.

23 Bond GG, McLaren EA, Cartmill JB, et al. Cause-specific mortality among male chemical workers. Am f Ind Med 1987;12:353-83.

24 Monson RR. Analysis of relative survival and proportional mortality. Computers and Biomedical Research 1974;7:32532 .

25 Steenland K, Spaeth S, Cassinelli II R, et al. NIOSH life table program for personal computers. Am f Ind Med 1998;34:517-18.

26 Hakulinen T. A Mantel-Haenszel statistic for testing the association between polychotomous exposure and a rare outcome. Am f Epidemiol 1981;113:192-6.

27 Mantel N. Chi-square tests with one degree of freedom. Extensions of the Mantel-Haenszel procedure. Fournal of the American Statistical Association 1963;58:690-700.

28 Checkoway H, Pearce N, Hickey JLS, et al. Latency analysis in occupational epidemiology. Arch Environ Health 1990; 45:95-100.

29 Charles JM, Bond DM, Jeffries TK, et al. Chronic dietary toxicity/oncogenicity studies on 2,4-dichlorophenoxyacetic toxicity/oncogenicity studies on 2,4-dichlorophenoxyac
acid in rodents. Fundam Appl Toxicol 1996;33:166-72.

30 Charles JM, Dalgard DW, Cunny HC, et al. Comparative subchronic and chronic dietary toxicity studies on 2,4subchronic and chronic dietary toxicity studies on 2,4-
dichlorophenoxyacetic acid, amine, and ester in the dog. Fundam Appl Toxicol 1996;29:78-85. 
31 Blair A, Zahm SH, Pearce NE, et al. Clues to cancer etiology from studies of farmers. Scand 7 Work Environ Health 1992, 18:209-15.

32 Zahm SH, Ward MH, Blair A. Pesticides and cancer. Occupational Medicine: State of the Art Reviews 1997;12:269-89. 33 Blakley BR, Schiefer BH. The effect of topically applied n-butylester of 2,4-dichlorophenoxyacetic acid on the immune response in mice. $\mathcal{F}$ Appl Toxicol 1986;6:291-5.

34 Blakley BR. The effect of oral exposure to the n-butylester of 2,4-dichlorophenoxy acetic acid on the immune response in mice. Int F Immunopharmacol 1986;8:93-9.

35 Blakley BR, Blakley PM. The effect of prenatal exposure to the n-butylester of 2,4-dichlorophenoxyacetic acid (2,4-D) on the immune response in mice. Teratology 1986;33:15-20.

36 Faustini A, Settimi L, Pacifici R, et al. Immunological changes among farmers exposed to phenoxy herbicides: preliminary observations. Occup Environ Med 1996;53:583-5.

37 Mueller N. Another view of the epidemiology of nonHodgkin's lymphoma. Oncology 1994;8:83.

38 Hartge P, Devesa SS, Grauman D, et al. Non-Hodgkin's lymphoma and sunlight. $\mathcal{f}$ Natl Cancer Inst 1996;88:298300 .

39 Freedman DM, Zahm SH, Dosemci M. residential and occupational exposure to sunlight and mortality from nonHodgkin's lymphoma: composite (threefold) case-control study. BMF 1997;314:1451-5

40 Mattsson JL, Charles JM, Yano BL, et al. Single-dose and chronic dietary neurotoxicity screening studies on 2,4 dichlorophenoxyacetic acid in rats. Fundam Appl Toxicol 1997;40:111-19.

41 Nelson LM. Epidemiology of ALS. Clin Neurosci 1996;3: 327-31

42 Roman GC. Neuroepidemiology of amyotrophic lateral sclerosis: clues to aetiology ad pathogenesis. $\mathcal{F}$ Neurol Neurosurg Psychiatry 1996;61:131-7.

43 Chancellor AM, Slattery JM, Fraser H, et al. Risk factors for motor neuron disease: a case-control study based on patients from the Scottish Motor Neuron Disease Register. f Neurol Neurosurg Psychiatry 1993;56:1200-6.

44 Savettieri G, Salemi G, Arcara A, et al. A case-control study of amyotrophic lateral sclerosis. Neuroepidemiology 1991;10: $242-5$.

45 Deapen DM, Henderson BE. A case-control study of amyotrophic lateral sclerosis. Am f Epidemiol 1986;123:790-9.

46 McGuire V, Longstreth WT, Nelson LM, et al. Occupational exposures and amyotrophic lateral sclerosis. Am f Epidemiol 1997;145:1076-88.

47 Olsen GW, Gondek MR, Flannery J, et al. A 38 year comparison of cancer incidence and mortality among employees at a Connecticut chemical plant. Connecticut Medicine 1997;61:83-9.

48 Bond GG, Austin DF, Gondek MR, et al. Use of a population-based tumor registry to estimate cancer incidence among a cohort of chemical workers. f Occup Med 1988;30:443-8.

\section{Vancouver style}

All manuscripts submitted to Occup Environ $M e d$ should conform to the uniform requirements for manuscripts submitted to biomedical journals (known as the Vancouver style.)

Occup Environ Med, together with many other international biomedical journals, has agreed to accept articles prepared in accordance with the Vancouver style. The style (described in full in the $\mathcal{F} A M A[1])$ is intended to standardise requirements for authors, and is the same as in this issue.

References should be numbered consecutively in the order in which they are first mentioned in the text by Arabic numerals on the line in square brackets on each occasion the reference is cited (Manson[1] confirmed other reports [2][3][4][5]). In future references to papers submitted to Occup Environ Med should include: the names of all authors if there are three or less or, if there are more, the first three followed by et al; the title of journal articles or book chapters; the titles of journals abbreviated according to the style of Index Medicus; and the first and final page numbers of the article or chapter. Titles not in Index Medicus should be given in full.

Examples of common forms of references are:

1 International Committee of Medical Journal Editors. Uniform requirements for manuscripts submitted to iomed journals. $\mathcal{} A M A 1993 ; 269$.

2 Soter NA, Wasserman SI, Austen KF. Cold urticaria: release into the circulation of histmaine and eosinophil chemotactic factor of anaphylaxis during cold challenge. N Engl F Med 1976;294:687-90.

3 Weinstein L, Swartz MN. Pathogenic properties of invading micro-organisms. In: Sodeman WA Jr, Sodeman WA, eds. Pathologic physiology, mechanisms of disease. Philadelphia: W B Saunders, 1974:457-72. 